\title{
The Implementation of School-Based Management in Extracurricular Robotics Execution at Elementary School
}

\author{
R. M. S. Yusuf, Karwanto, Y.Riyanto \\ Universitas Negeri Surabaya \\ Surabaya, Indonesia \\ m.enterpreneur@gmail.com
}

\begin{abstract}
The purpose of this study is to describe and analyze: 1) the implementation of school-based management in robotics extracurricular at SD Muhammadiyah 4; 2) factors supporting the implementation of school-based management in robotics extracurricular at SD Muhammadiyah 4; 3) and inhibiting factors of the implementation school-based management of robotics extracurricular at SD Muhammadiyah 4. This is a case study research. Data collection techniques are using in-depth interviews, participant observation and documentation. The results showed that the implementation of school-based management is in accordance with the characteristics and the framework of school-based management well, including cooperation and communication between schools, parents, students synergized. Factors supporting the implementation of school-based management are high community participation, complete learning tools, learning process using the PAKEM approach. Inhibiting factors in the implementation of the lack of affordable facilities and infrastructure as the main media for the process of extracurricular robotics activities is less stable for the learners.
\end{abstract}

Keywords - Implementation, School-Based Management, Extracurricular

\section{INTRODUCTION}

A good quality of education will arise if in the achievement of the purpose is getting support from various parties, whether from the internal education such as school autonomy as well as external parties such as community participation. As stated in Act No. 20 of 2003 paragraph 1, section 3 which states that "The national education system is an integral component of education in an integrated manner to achieve the goals of national education".

School-based management programs, school managers are given the authority to make decisions more closely and in accordance with the interests of school residents, learners, and the community and other stakeholders. Thus, the school can run the program more relevant to the needs, and accountable and transparent.

Suparlan (2014: 61) explains that the implementation of school-based management can be done on several components, among others: "(1) curriculum and learning;
(2) learners; (3) educators and education personnel; (4) financing; (5) facilities and infrastructure; (6) school and community relations; (7) school culture and environment ".

SD Muhammadiyah 4 Surabaya is one of the schools that have implemented School-Based Management. Uniquely, this school is one of the private elementary schools that has the title of National School in Surabaya. That owned an intensive coaching, and student guardian support in the facilities. SD Muhammadiyah 4 Surabaya is capable of achievement.

This success begins with the effort or role of all components of the school that include: curriculum and teaching program management, personnel management, student management, financing management, facilities and infrastructure management, school relationships with community management, special service management. Examples of business undertaken by all components of the school as follows: 1) socializing extracurricular activities robotics to the guardian of the pupil; 2) registering students interested in extracurricular activities of robotics; 3) conducting special selection of learners in extracurricular activities robotics aim to capture learners who have potential in the field of robotics; 4) conducting intensive training or coaching; 5) following the robotics race; 6) conveying to the students' guardian about extracurricular financing robotics, this financing includes: the cost of accommodation at the time of the race, the procurement of tools (robots) sourced at the cost of the individual.

Based on the above review, it noted that SD Muhammadiyah 4 Surabaya excels in the field of nonacademic. In this case, researchers want to know the extracurricular management, especially the robotics extracurricular in the school.

\section{LITERATURE REVIEW}

Depdiknas (2007), devined the school-based management as a management model that provides greater autonomy or authority and responsibilities for principals, 
and provides principal flexibility and encourages direct participation of school's member (teachers, students, principals and etc).

Caldwell (Rini, 2011: 8) defined school-based management as a systematic decentralization of authority and school-level responsibilities to make decisions on significant problems related to school administration within a framework set by the central government regarding policy objectives, curriculum, standards and accountability. So, schools should control all resources and use them more efficient, since those resources are beneficial for the improvement quality in particular. It is concluded that school-based management is a form of school authority to implement a series of school activities by involving all school members and stakeholders to achieve the school's objectives.

The activities of the implementation of school-based management consist of planning, organizing, actuating, and controlling.

\section{A. Planning}

According to Siagian (Usman, 2009: 65-66), planning is a whole process of thought and determination in a mature and manner concerning the things that will be done in the future in order to achieve a predetermined goal. Based on the description above it can be concluded that planning is an activity that can support any activities in the future to achieve the goal. From this definition the planning contains 2 elements, as follows: 1) a number of activities that are predetermined; 2) the process, and 3) the results to be achieved.

\section{B. Organizing}

According to Terry (Mulyono, 2008: 27), organizing is an effective behavioural relationship among personnel, so that they can cooperate efficiently and obtain personal decisions in carrying out tasks in the environmental situations in order to achieve certain goals and targets.

\section{Actuating}

Actuating means the implementation of the plan that has been prepared. In the actuating also motivated, directed, supervised and monitored.

The principles of actuating include; (1) the establishment of operational standards for activities; (2) the determination of the activities success; and (3) the development of activities or corrective actions if necessary.

\section{Controlling}

According to Suherman (1988), monitoring can be interpreted as an activity, to keep abreast of a program that is carried out steadily and regularly and continuously. Supervision can use direct and indirect approaches. The direct approach is carried out if the party that monitors is carrying out its activities at the location of the program being implemented. The techniques that are often used in this approach are interviews and observations. This technique is used to monitor the activities, events, components, processes, results and effects of the implemented programs.

There are several components that must be managed well in SBM. These components include curriculum management, students management, educators management and education personnel, school facilities and infrastructure management, financing management, and management of the school relations with the community. This study related to one of the components of school-based management, namely student management.

Student management is the structuring and regulating activities related to students, starting from they enter the school until they leave (Mulyasa, 2005: 46). According to Suharno (2008: 26), student management or discipleship management is one of the operational fields. Student management function as a vehicle to develop students optimally both individually and socially in accordance with potential and or special needs.

Students management is the main indicator of the success of robotics extracurricular activities. The purpose of extracurricular activities is to trigger and encourage students to improve the skills in designing, assembling and programming robots that can hone their creativity to accomplish some achievements.

According to Wahjosumidjo (Kompri, 2015: 225) extracurricular activities are student's activities outside of school hours conducted outside of school, with the aim of broadening knowledge, understanding the interrelationships between various subjects, channeling talents and interests, and in order to improve their quality faith to the God Almighty, awareness of nation and state, virtuous noble character.

According to Septiani \& Wiyono (2012: 425), extracurricular activities are not just a place to channel students' hobbies. If it channeled effectively, especially based on physical activities, it can shape the students' character. Besides, extracurricular activities is one element in the effort to build students' personality.

The benefits of learning robotics can stimulate systematic and structured thinking in solving a problem, improving children's fine motor skills, improving imagination skills in designing a robot, because in designing robots it needs creativity, training in groups and increasing self-confidence, accept and respect the opinions of others 
and dare to express or display his creative ideas, to practice patience and persistence in making a project.

\section{METHODS}

This research uses the qualitative approach with case study research type. Data collection techniques used are indepth interviews, participant observation and documentation. According to Narbuko and Achmadi (2013) interview is a question-and-answer process in research that takes place orally between two people or more face-to-face listening directly information or explanations. An in-depth interview is an activity conducted to obtain information directly by expressing the questions to the informants. In qualitative research, in-depth interviews became the main tool combined with participant observation.

Riyanto (2007: 26) explains that at the time of observation interwoven the intensive social interaction between researchers with the subjects residing in the study site. According to Lincoln and Guba (Riyanto, 2007: 1722), there are at least four main criteria to ensure the reliability of qualitative research results that include: (1) credibility (2) dependability, (3) confirmability, (4) transferability. In testing the degree of confidence in the data studied, researchers used prolonged engagement.

According to Riyanto (2007: 17), "the length of time for qualitative researchers to stay in the place of research cannot be established and depends on the narrowness or breadth of the scope of research focus". In this case, the researcher conducting research where and for some time that is from November 2017 until May 2018. Data analysis technique using descriptive analysis through three steps are (1) condensation data, (2) data presentation, (3) drawing conclusion.

Data condensation is the process of selecting, simplifying, abstracting, and transforming data close to the whole of the field records in writing, transcripts, interviews, documents, and other empirical materials.

Presentation of data is a process of displaying data simply in the form of words, sentences, narratives, brief descriptions, charts, tables, graphs, flowcharts, matrices and so on with the intention that the data has been collected mastered by researchers as the basis for drawing the right conclusions.

Miles, Huberman and Saldana (2014: 31) explain that this step is where the conclusions are drawn. In the phase of drawing conclusions/verification in this data analysis technique, the researchers tried to draw conclusions based on the title to find the meaning of the collected data. The data display is used for data interruptions. Conclusions are drawn after cross-checking against other sources through interviews, observations and observations. So with the process of data analysis, the researcher can answer the focus of research that requires answers by doing research in SD Muhammadiyah 4 Surabaya.

\section{RESUlt AND DisCUSSION}

\section{A. Result}

This study presents data that obtained through participant observation, in-depth interviews and documentation. These data include:

1) The implementation of school-based management in the implementation of robotics extracurricular.

a. The planning program of robotics extracurricular activity is divided into two, namely regular program and intensive program, where the purpose of this intensive program is to make students more skilled in designing, designing, programming robot and achieving the championship.

The recruitment of robotics extracurricular trainers is through recommendations in accordance with the consideration and need for the quantity and quality of the robotics activities. Sources of financing the implementation of robotics extracurricular activities are obtained from two sources, namely school and guardian.

b. Organizing in managing the implementation of the robotics extracurricular program involves the school's citizens in accordance with their roles and duties in each field. From the organizing activities it is clear that there is good cooperation between each stakeholder. The existence of reporting related to robotics extracurricular activities is clearly reported by the robotics responsible to the extracurricular coordinator, then from the extracurricular coordinator reported to the principal after the approval by the principal and then submitted in a transparent manner to the guardian through a meeting.

c. Controlling of a program that has been established by stakeholders must be in line with the existing conditions, both in the field and outside the field, which in its activities involves several elements accompanied by efforts and supported by all the needs, the necessary tools, who carries out, where the place of execution began and how it should be implemented. In this case, related to the implementation of robotic extracurricular activities program.

d. Controlling is the process of observing the implementation of all activities of the organization, in this case, related to extracurricular activities. To ensure that all work is underway and carried out in accordance with predetermined plans. Controlling is the responsibility of the leader, but because it is impossible for the leader to do everything then the controlling is by delegating one person in charge of robotics.

The function of controlling in the implementation of robotics extracurricular program are to analyze the teaching and learning situation of extracurricular activities of robotics, stimulate the creative efforts of the robotics responsible, help to improve the teaching ability of the trainer. Controlling and directing facilities and infrastructure 
in the implementation of robotics extracurricular activities could make the process more effective and efficient.

2) Supporting factors that support the success of the implementation of school-based management in the robotics extracurricular are: high school community participation, complete learning tools, learning process using PAKEM, good management, Schools, pupils and learners synergized and good cooperation.

\section{3) Inhibiting factors}

In the successful implementation of school-based management in the implementation of robotics extracurricular must have an obstacle. The obstacles for the procurement of facilities and infrastructure (robot tool) needs a planning and organizing of the mature person in charge, that coordinated directly with parents through the meeting. Meanwhile, to overcome the sense of saturation of learners it needs the cooperation with the students' guardian.

\section{B. Discussion}

According to Darnalita (2014: 830) the implementation of School-Based Management must change the learning system or model that has been centred on the teacher into a learning-oriented or student-centred system or model such as Active, Creative, Effective, and Joyful Learning models.

Siagian (Usman, 2009: 65-66) stated that planning contains 3 elements: 1) a number of activities that are predetermined; 2) the process; 3 ) results to be achieved.

Mulyasa (2007: 35) stated that the characteristics of SBM include the provision of broad autonomy to schools, it means that the schools as educational institutions that are given broad authority and power to develop curriculum and learning programs according to the students' conditions and needs based on the demands of the community. Besides that, in School-Based Management, the implementation of school programs is supported by the participation of the community and parents. Communities and parents collaborate to help schools as persons resource of various school activities to improve the quality of learning.

The results of the research that are related to the theory can be said that the planning of the robotics extracurricular activity program is in accordance with the characteristics and principles of school-based management namely independence and participatory. As an indicator, there is a plan that always involves stakeholders consisting of the Principal, Deputy Principal, Head of Curriculum and Student Affairs, Extracurricular Coordinator, Extracurricular Robotics.

Nurkholis (2003: 46) stated that labour-management starting from the analysis of planning, recruitment, development, rewards and sanctions is needed to evaluate the performance of school workers that can be done by schools except for civil servant teachers who are still handled by the bureaucracy above.

\section{Supporting factors}

The success of implementation of robotics extracurricular activities cannot be separated from the factors that support the effectiveness of the implementation of school-based management, among others they are known to have stakeholder involvement, the arrangement of program activities extracurricular robotics, predetermined routine activity schedules, facilities and infrastructure facilities, management of a good responsible person, trainers who are competent in the field of robotics, establish good communication, coordination and cooperation that synergize with the community, and students' interests.

According to Saud (Hendrawati, 2012) factors that are considered essential in supporting the effectiveness of the implementation of school-based management practically at the school level include the following aspects. 1) Clear Authority and Autonomy of School Institutions; 2) Practice of Democratic Leadership and Decision Making; 3) Empowering Effective Education Facilities in Supporting Learning Programs; 4) Development of Professional Performance and "Team work" Work Culture between School Leaders and Teachers. In addition, school leaders and teacher are required to demonstrate high professional performance in their work.

High and Intensive Community and Parental Participation: The implementation of SBM will be effective if the community and parents provide high support and participation in school programs. Whereas According to Nurkholis (2003: 264) there are six factors supporting the successful implementation of SBM including (1) Political will, (2) Finance, (3) Human resources, (4) School culture, (5) Leadership, (6) Organization.

The opportunity for successful implementation of SBM in Indonesia is currently quite large due to several factors, including: (1) Demands for a considerable democratization life from the community in the reform era, (2) Application of Act No. 22 of 1999 concerning local government which emphasizes the autonomy of government at the district / city level, (3) The existence of school committees that function to assist in the implementation of education safety network programs (JPS) in schools, (4) There is a government desire to increase community participation in education by increasing the duties, functions and auxiliary bodies of education implementation, (5) Quality improvement is obtained through parents, flexibility in school management, improvement of teacher professionalism, gifts and penalties as controls and things that can grow an existing one.

The results of this study can already be related to the theory in the previous paragraph that the factors supporting the implementation of school-based management in the implementation of robotics extracurricular in the senior high school are the community participation, learning tools, the learning process using PAKEM, good educators (underwriters/ trainer), good management, good communication and cooperation that synergize between 
school, student guardian and students. So, it can be said that school management is essentially not the authority and obligation of the school principal but the school in its management is expected to involve existing stakeholders because the involvement of stakeholders is one of the basic capitals to support the realization of implementation SBM in schools.

\section{Inhibiting factors}

The results of the research in the previous chapter explained that one of the obstacles of the implementation the robotics extracurricular activities is the need for facilities and infrastructure (robot tools) which are used as the main media in the process of extracurricular activities of robotics.

According to Saud (Hendrawati, 2012) the management of professional education institutions must be done and it should not be left behind by the flow of information and globalization and can answer the current challenge because the tasks of educational institutions is so heavy. obstacles in the management of SBM are: First, students are one of the main factors of education that can affect the success of teaching and learning process. Second, Educators: The family's state of health, sociology, psychology and economic well-being is a barrier or social factor that can affect the progress of teacher duties, undesirable psychological social climates, the health of families who do not meet the health requirements in their less favourable economic welfare state can interfere with their duties at school. Third, Funds and infrastructure: the lack of funding and infrastructure is a problem of education in Indonesia. Fourth, community participation: community participation is very influential in the course of school management because the community that determines the direction and purpose of education.

With regard to the factors causing the failure of MPMBS, Wohlstetter and Mohrmann policy implementation (Hamzah, 2013: 170), revealed four types of implementation failure are: 1) simply adopting the model as it is or no creative effort; 2) the principal is based on his own work without considering the aspirations of the school community; 3) decision-making power is centred on one party. Meanwhile, according to Rosyada (Sunarto, 2012: 346), some obstacles that may be faced by interested parties in the application of SBM include: not interested in being involved, inefficient and group thoughts.

From some of the above opinions it can be concluded that the success of SBM will be hampered if all components of the school can not work together to realize the purpose of the school. Besides, the level of knowledge on the implementation of SBM is also very influential, as well as the role of principal as the central in the school is not maximal and head the school cannot manage the members of the organization.

\section{CONCLUSION}

Based on the results of research and discussion it can be concluded as follows:

1. The result of the robotics extracurricular activities program management is said to be good because of the cooperation and communication between schools, parents, and students synergize each other.

2. The success of the implementation of robotics extracurricular activities is said to be effective because it cannot be separated from the factors that support the implementation of school-based management in accordance with the functions of management, among others:

a. High community participation.

b. Complete learning device.

c. The learning process uses PAKEM.

d. The existence of communication, collaborative cooperation between schools, guardians of students, and students.

e. Educators who have good quality and quantity.

3. The inhibiting factors in the implementation of schoolbased management in implementing robotics extracurricular activities as follows:

a. Procurement of facilities and infrastructure is not affordable.

b. student performance is Less stable when participating in extracurricular activities.

\section{Acknowledgement}

The research involves many parties, for that, the gratitude and appreciation are delivered especially to the teacher of robotics extracurricular, who have taken the time to teach which is done in earnest and full of responsibility.

\section{References}

[1] Riyanto, Yatim. Qualitative and Quantitative Research Methodology. UNESA University Press. 2007

[2] Nurkolis. Manajemen Berbasis Sekolah (teori, model, dan aplikasi) Jakarta: PT Gramedia Widiasara Indonesia. 2003

[3] Mulyasa, Enco, Manajemen Berbasis Sekolah: Konsep, Strategi, dan Implementasi, Bandung: Remaja Rosdakarya. 2009

[4] Narbuko, Achmedi, Metodelogi Penelitian, Jakarta: Bumi Aksara. 2010

[5] Rohiat. Manajemen Sekolah. Bandung: PT Refika Aditama. 2008.

[6] Bandur, Agustinus. "School Based Management Developments: Challenges and impacts". Journal of Educational Administration. Vol.50 No.6. 2012

[7] Botha, Nico. Leadership in School-Based Management: A Case Study in Selected". South African Journal of Education. Vol.26 No.31. 2006

[8] Cahyana, Ade. "Upaya Peningkatan Mutu Sekolah Melalui Otonomi Satuan Pendidikan". Jurnal Pendidikan dan Kebudayaan. Vol.16, No.2. 2010 
[9] Cook, Thomas D. "School-Based Management: A Concept of Modest Entitativity with Modest Result". Journal of Personel Evaluation in Education. Vol.20 No.17. 2007

[10] Darnalita, Silvia Fitri. "Upaya Kepala Sekolah untuk Meningkatkan Implementasi Manajemen Berbasis Sekolah di SMP Pembangunan Laboraturium UNP". Bahana Manajemen Pendidikan Journal Administrasi Pendidikan FIP UNP. Vol.2 No.1. 2014

[11] Fattah, Konsep Manajemen Berbasis Sekolah (MBS) Dan Dewan Sekolah, Bandung, C.V. Pustaka Bani Quraisy. 2004

[12] Pushpanadham, K. "Educational Leadership for School-Based Management.” ABAC Journal. Vol.26 No.1. 2006

[13] Prabhakar, N.P and Rao, K.V. (2011). "School-Based Management: An Analysis of The Planning Framework and Community Participation". International Refereed Research Journal. Vol.2 No.3.

[14] Brown, D.J. 1990. Decentralization and school-based management. London: The Falmer Press.

[15] Bullock, A.; Thomas, H. 1997. Schools in the centre?: a study of decentralisation. London: Routledge.
[16] Caldwell, B.J. 1993b. "The changing role of the school principal: a review of developments in Australia and New Zealand." In Dimmock, C. (ed.). School-based management and school effectiveness. London: Routledge.

[17] Caldwell, B.J. 1997. "Local management of schools and improved outcomes for students". Paper presented in a symposium onthe theme International advances in school effectiveness and improvement, sponsored by the International Congress for School Effectiveness, conducted at the Annual General Meeting of the American Educational Research Association, Chicago, 24-29 March 1997.

[18] Sagala, 2013, Manajemen Strategik Dalam Peningkatan Mutu Pendidikan, Bandung, ALFABETA.

[19] Septiani, Irma, dan Bambang Budi Wiyono. (2012). Manajemen Kegiatan Ekstrakurikuler Dalam Meningkatkan Kualitas Sekolah. Jurnal Manajemen Pendidikan. Vol.23 No.5.

[20] Departemen Pendidikan Nasional. 2007. Manajemen Berbasis Sekolah. Jakarta: Departemen Pendidikan Nasional. 